\title{
The effect of concentrate supplementation type on milk production, dry matter intake, rumen fermentation, and nitrogen excretion in late-lactation, spring-calving grazing dairy cows
}

\author{
Z. C. McKay, ${ }^{1}$ M. B. Lynch, ${ }^{1}$ F. J. Mulligan, ${ }^{2}$ G. Rajauria, ${ }^{1}$ C. Miller, ${ }^{3}$ and K. M. Pierce ${ }^{1 *}$ \\ ${ }^{1}$ School of Agriculture and Food Science, University College Dublin, Lyons Research Farm, Lyons Estate, Celbridge, Naas, Co. Kildare, \\ Ireland W23 ENY2 \\ ${ }^{2}$ School of Veterinary Medicine, University College Dublin, Belfield, Dublin 4, Ireland D04 W6F6 \\ ${ }^{3}$ Gain Feeds, Glanbia Plc., Bridge Street, Portlaoise, Ireland R32 ND7A
}

\section{ABSTRACT}

In Ireland, milk is primarily produced using a springcalving grass-based system, with the use of concentrate supplementation mainly when pasture availability and quality are reduced. In the autumn, when cows are in late lactation, reduced pasture productivity results in reduced milk yield and altered milk composition. Nitrogen utilization efficiency also reduces as lactation progresses. Concentrate supplementation has been found to increase milk production and reduce nitrogen $(\mathrm{N})$ excretion, as high-N grass is usually replaced by a lower- $\mathrm{N}$ supplement; however, there is a paucity of information with regard to the optimum type of supplementation in late lactation. Therefore, the objective of this research is to investigate the effect of different concentrate supplementation types, based on barley or maize, on milk production, dry matter intake (DMI), rumen fermentation, and $\mathrm{N}$ excretion in late-lactation, spring-calving, grazing dairy cows. Thirty-six Holstein Friesian dairy cows were blocked on days in milk (185 DIM) and balanced for parity, pre-experimental milk yield, milk composition, and body condition score. Cows were randomly assigned to 1 of 3 dietary treatments in a randomized complete block design $(\mathrm{n}=12)$. The 3 treatments consisted of a perennial ryegrassbased pasture-only (PO) treatment and pasture plus either of 2 supplementary concentrates, based on barley $(\mathrm{PB})$ or maize $(\mathrm{PM})$. The diets were fed for a 14-d acclimatization period and then for a further 63-d experimental period. Cows offered PO had a lower daily milk yield $(15.1 \mathrm{~kg})$ than PB $(18.2 \mathrm{~kg})$ or PM $(16.8 \mathrm{~kg})$. Similarly, PO had lower daily milk solids yield (1.46 $\mathrm{kg}$ ) than $\mathrm{PB}$ or PM (1.68 and $1.53 \mathrm{~kg}$, respectively).

Received October 4, 2018.

Accepted February 20, 2019.

*Corresponding author: karina.pierce@ucd.ie
Cows offered PB had a greater milk yield and higher fat and protein yields than those offered PM. Offering PB increased total DMI $(19.5 \mathrm{~kg})$ compared with PO (17.7 $\mathrm{kg}$ ), and milk response to concentrates was also greater for PB compared with PM (1.21 vs. $0.71 \mathrm{~kg}$ of milk per $\mathrm{kg}$ of concentrate). Cows offered PB had increased $\mathrm{N}$ in milk compared with PO. In conclusion, concentrate supplementation based on barley or maize resulted in increased milk and milk solids yield compared with offering PO. Cows offered barley had a greater response to concentrates and increased milk and milk solids yield in comparison to maize and showed increased $\mathrm{N}$ partitioning in milk compared with PO. A barley-based concentrate increased total DMI compared with PO. Key words: dairy cow, concentrate supplementation, grazing, late lactation, milk production

\section{INTRODUCTION}

Milk production in Ireland primarily uses a springcalving grazing system, with concentrate supplementation used mainly to compensate for reduced availability and quality of pasture (Coleman et al., 2010; Creighton et al., 2011; McCarthy et al., 2013). The main competitive advantage of pastoral systems globally is the lower cost of production, because pasture is a cheap nutrient source (Auldist et al., 1998; Lacy-Hulbert et al., 1999; Burke et al., 2008; Finneran et al., 2010). However, changes in pasture quality and pasture deficits can occur in the autumn, which can limit milk production (Auldist et al., 1998; Burke et al., 2008; Creighton et al., 2011) and alter milk composition in late lactation, resulting in problems with milk processability (Lucey and Fox, 1992; O'Brien et al., 1996; Auldist et al., 1998).

During the term of European Union milk quotas (1983-2015), many farmers opted for a shorter lactation due to quota restrictions; however, since quota abolition, the opportunity exists to expand dairy en- 
terprises and continue milking later into the year if it makes economic sense to do so. Dairy cow numbers in Ireland have increased 19\% from 2014 to 2017 (CSO, 2017a), and cows are milking later into lactation, with a $13 \%$ increase in milk intake by creameries in December 2017 compared with December 2015 (CSO, 2015, CSO, 2017b). This expansion has resulted in an increased focus on grass quality and availability in the autumn and subsequently its effects on milk production and composition. The resultant nitrogen (N) excretion is also of interest, particularly because nitrogen utilization efficiency (NUE) decreases as lactation progresses (Castillo, 2001).

In the autumn, when cows are in late lactation, concentrate feeds are often offered as supplements to grazed pasture (Lacy-Hulbert et al., 1999; Reid et al., 2015) to increase DMI, increase milk production, and extend the lactation length (Bargo et al., 2003). Concentrate supplementation in late lactation has been found to increase milk yield and milk solids yield and improve NUE, compared with pasture-only diets (O'Brien et al., 1996; Reid et al., 2015). However, research with dairy cows in late lactation at pasture is limited, and the main focus of such research has been on comparing supplementation with concentrates or grass silage (O'Brien et al., 1996; Reid et al., 2015).

Improvements in milking performance and NUE of late-lactation cows may be possible by altering the starch type and the site of starch digestion (HerreraSaldana et al., 1990). Offering maize corn as a direct replacement for barley should increase the postruminal supply of starch (Ørskov, 1986) and may therefore reduce urinary $\mathrm{N}$ excretion via improvements in milk and fecal N partitioning (Kebreab et al., 2000; Castillo, 2001). Whelan et al. (2012a,b) demonstrated that maize performed better than barley when offered to early-lactation dairy cows as a concentrate supplement $(5.17 \mathrm{~kg} / \mathrm{d})$ to pasture, with an increase in milk yield, protein, and casein yield, higher lactose content, and reduced urinary $\mathrm{N}$ excretion observed. However, this response may be specific to stage of lactation, nutritional requirements, pasture quality, and concentrate level and may not reflect the response from cows in late lactation offered autumn pasture, which is generally of poorer quality than spring pasture (Coleman et al., 2010; McCarthy et al., 2013).

The objective of this research was therefore to investigate the effects of different concentrate supplementation types based on barley or maize, on milk production, milk composition, DMI, rumen fermentation, and $\mathrm{N}$ excretion in late-lactation, spring-calving grazing dairy cows. We hypothesized that offering concentrate supplementation to dairy cows in late lactation at autumn pasture would improve milk production and milk composition and, furthermore, that supplementation with a maize-based supplement would have benefits over a barley-based supplement.

\section{MATERIALS AND METHODS}

\section{Cows, Treatments, and Experimental Design}

The Animal Research Ethics Committee at University College Dublin (UCD) approved all of the procedures described in this experiment. These procedures were conducted under experimental license (AE18982/ I005) from the Health Products Regulatory Authority under the European directive 2010/63/EU and SI No. 543 of 2012. Each person who carried out procedures on experimental cows during the course of this experiment was licensed to do so by means of individual authorization from the Health Products Regulatory Authority.

Thirty-six dairy cows (Bos taurus strain Holstein Friesian) were selected from the spring-calving dairy herd at UCD Lyons Research Farm, Co. Kildare, Ireland $\left(53^{\circ} 17^{\prime} 56^{\prime \prime} \mathrm{N}, 6^{\circ} 32^{\prime} 18^{\prime \prime} \mathrm{W}\right)$. The cows were blocked on DIM (average 185 DIM) and balanced for parity, milk yield, milk composition (fat \%, protein \%, and milk solids yield), and BCS. Cows were assigned to 1 of 3 pasture-based dietary treatments in a randomized complete block design $(\mathrm{n}=12)$. The 3 treatments consisted of a perennial ryegrass-based pasture-only (PO) treatment or pasture plus 1 of 2 supplementary concentrates, based on either barley $(\mathbf{P B})$ or maize $(\mathbf{P M})$. Cows were offered the supplementary concentrate twice daily through the milking parlor (Feedrite automatic system, Dairymaster, Tralee, Ireland) at a rate of 2.65 $\mathrm{kg}$ of $\mathrm{DM} /$ cow per day (3 $\mathrm{kg}$ of fresh weight/cow per day). The supplementary concentrates were formulated using feed formulation software to be isonitrogenous $(16 \% \mathrm{CP})$ and were manufactured by Gain Feeds (Portlaoise, Ireland), where all ingredients were ground to form a pellet (Table 1 ).

Cows were observed while consuming the concentrates, and, given the low level of concentrate offered (1.33 kg morning and evening), animals consumed all concentrates offered; no refusals were recorded.

Cows were offered the experimental diets for a 14-d dietary acclimatization period. Following this, cows remained on their treatments for a further $63 \mathrm{~d}$ (Aug. 24 to Oct. 27, 2016). Measurements were taken weekly for $10 \mathrm{wk}$ for BCS, milk production, milk composition, blood glucose, rumen health parameters, ruminal $\mathrm{pH}$, VFA and ammonia $\left(\mathrm{NH}_{3}\right)$ concentration, and, during wk 5, pasture DMI and N partitioning.

All cows were grazed together in a single group in a strip-grazing system, to enable a fresh allocation of pasture twice daily (17 kg of DM/head per day above 
Table 1. Ingredient composition of experimental concentrates

\begin{tabular}{lrc}
\hline & \multicolumn{2}{c}{ Experimental concentrates $^{1}$} \\
\cline { 2 - 3 } Chemical composition, & PB & PM \\
g/kg of DM & 641 & - \\
\hline Barley & - & 643 \\
Maize & 216 & 237 \\
Soybean meal & 24 & 6 \\
Palm oil (mixer) & 6 & 60 \\
Palm oil (coater) & 60 & 7 \\
Molasses & 6 & 13 \\
Mono-dicalcium phosphate & 14 & 10 \\
Calcium carbonate & 7 & 20 \\
Sodium chloride & 21 & 5 \\
Magnesium oxide & 5 & \\
Gain Cattle premix & & \\
\hline
\end{tabular}

${ }^{1} \mathrm{~PB}=$ barley-based concentrate supplement; $\mathrm{PM}=$ maize-based concentrate supplement.

${ }^{2}$ Gain Cattle (Portlaoise, Co. Laois, Ireland) premix consisted of the following: $1.0 \mathrm{~g} / \mathrm{kg}$ of calcium, $0.5 \mathrm{~g} / \mathrm{kg}$ of phosphorus, $0.4 \mathrm{~g} / \mathrm{kg}$ of sodium, $1.03 \mathrm{~g} / \mathrm{kg}$ of potassium, $0.79 \mathrm{~g} / \mathrm{kg}$ of chlorine, $1.16 \mathrm{~g} / \mathrm{kg} \mathrm{mag-}$ nesium, $46.52 \mathrm{mg} / \mathrm{kg}$ of copper, $0.18 \mathrm{~g} / \mathrm{kg}$ of sulfur, $8,000 \mathrm{IU} / \mathrm{kg}$ of vitamin $\mathrm{A}, 2,000 \mathrm{IU} / \mathrm{kg}$ of vitamin $\mathrm{D}, 10 \mathrm{IU} / \mathrm{kg}$ of vitamin $\mathrm{E}$ for the maize concentrate; and $1.0 \mathrm{~g} / \mathrm{kg}$ of calcium, $0.5 \mathrm{~g} / \mathrm{kg}$ of phosphorus, $0.3 \mathrm{~g} / \mathrm{kg}$ of sodium, $1.06 \mathrm{~g} / \mathrm{kg}$ of potassium, $0.65 \mathrm{~g} / \mathrm{kg}$ of chlorine, 1.21 $\mathrm{g} / \mathrm{kg}$ of magnesium, $47.34 \mathrm{mg} / \mathrm{kg}$ of copper, $0.22 \mathrm{~g} / \mathrm{kg}$ of sulfur, 8,000 $\mathrm{IU} / \mathrm{kg}$ of vitamin A, 2,000 IU $/ \mathrm{kg}$ of vitamin D, $10 \mathrm{IU} / \mathrm{kg}$ of vitamin $\mathrm{E}$ for the barley concentrate.

$4 \mathrm{~cm}$ ) and had ad libitum access to fresh water. The pre-grazing herbage mass was measured weekly before cows entered a new paddock, using a rising plate meter (diameter $355 \mathrm{~mm} ; 3.2 \mathrm{~kg} / \mathrm{m}^{2}$; Jenquip, Feilding, New Zealand) by walking in a $\mathrm{W}$ shape across the field. The Agrinet grass software system (Irish Farm Computers Ltd., Kells, Ireland) was used to monitor pasture growth and to ensure that the correct allocation of 17 $\mathrm{kg}$ of $\mathrm{DM} /$ head per day was met. Average pre-grazing herbage mass was $1,552 \mathrm{~kg}$ of $\mathrm{DM} /$ ha (above $4 \mathrm{~cm}$ ), with an average pre-grazing sward height of $10 \mathrm{~cm}$ (above ground level). Average post-grazing mass was $470 \mathrm{~kg}$ of DM/ha, with an average post-grazing height of $5.3 \mathrm{~cm}$.

\section{Data and Sample Collection}

Pasture and Feed Collection. Pasture quality was determined using the quadrat and shears method as described by Whelan et al. (2012a). Quadrat samples were taken pre-grazing by taking 2 quadrat $(0.5 \times 0.5$ $\mathrm{m}$ quadrat) cuts per allocation (2 morning and 2 evening) and harvesting to $4 \mathrm{~cm}$. These samples were then pooled to determine DM. Pasture samples were pooled weekly for proximate analysis (DM, gross energy, ether extract, ash, and $\mathrm{CP}$ ), NDF, ADF, and water-soluble carbohydrate (WSC) analysis (Table 2 and Figure 1). Concentrate samples were taken weekly and pooled for the duration of the experiment for proximate analysis, NDF, ADF, and starch analysis.

Cow Measurements. Cows were milked twice daily at 0700 and $1500 \mathrm{~h}$, with milk yield and composite milk samples facilitated using the Weighall milk metering and sampling system (Dairymaster). Milk samples were taken weekly from one successive morning and evening milking and pooled on a per-cow basis according to milk yield (Figure 2). Milk pH was measured immediately after morning and evening milk sampling (EC-25 $\mathrm{pH} /$ Conductivity Portable Meter, Phoenix Instrument, Garbsen, Germany) and averaged per day.

Cows were weighed twice daily after milking, using electronic scales as they left the parlor through the automatic drafting unit (Dairymaster), and averaged on a daily basis. Body condition scoring was determined weekly by a single fully trained operator using a scale of 1 to 5 with 0.25 increments according to Edmonson et al. (1989).

Blood samples were harvested by jugular venipuncture weekly following evening milking. Blood samples for glucose analysis were harvested into a 4-mL glucose Vacutainer (BD Vacutainer Systems, Plymouth, UK), which were stored on ice and centrifuged at 2,100 $\times$ $g$ for $20 \mathrm{~min}$ at $4^{\circ} \mathrm{C}$ for extraction of blood plasma. The blood plasma was drained off and frozen at $-20^{\circ} \mathrm{C}$, pending further analysis.

Rumen fluid samples were harvested weekly via Flora Rumen scoop oral esophageal sampler (Prof-Products, Guelph, ON, Canada), directly following evening milking at $1600 \mathrm{~h}$, after cows received their concentrate feed. Rumen fluid samples were analyzed immediately for $\mathrm{pH}$ (EC-25 pH/Conductivity Portable Meter, Phoenix Instrument). Once collected, samples were strained

Table 2. Chemical composition ( $\mathrm{g} / \mathrm{kg}$ of DM unless otherwise noted) of experimental treatments

\begin{tabular}{lccc}
\hline & \multicolumn{3}{c}{ Experimental feedstuffs } \\
\cline { 2 - 4 } Chemical & & \\
\cline { 2 - 4 } composition & PO & PB & PM \\
\hline DM & 125 & 863 & 847 \\
CP & 236 & 177 & 180 \\
Ash & 98 & 81 & 83 \\
Crude fiber & - & 40 & 42 \\
NDF & 490 & 161 & 141 \\
ADF & 236 & 95 & 95 \\
Ether extract & 32 & 26 & 14 \\
WSC & 113 & - & - \\
Starch & - & 349 & 413 \\
Gross energy, MJ/kg & 17.2 & 17.5 & 16.7 \\
\hline
\end{tabular}

${ }^{1} \mathrm{PO}=$ pasture-only diet; $\mathrm{PB}=$ pasture plus barley-based concentrate supplement; $\mathrm{PM}=$ pasture plus maize-based concentrate supplement. ${ }^{2}$ Water-soluble carbohydrate. 
through 4 layers of cheesecloth, and a $4-\mathrm{mL}$ aliquot was taken using an automatic pipette, mixed with 1 $\mathrm{mL}$ of trichloroacetic acid $(500 \mathrm{~g} / \mathrm{L})$, and cooled on ice. These were stored $\left(-20^{\circ} \mathrm{C}\right)$ pending analysis for VFA and $\mathrm{NH}_{3}$.

Nitrogen Partitioning Study. Nitrogen partitioning was determined during wk 5 of the study $(220 \pm$ 60 DIM; mean \pm SD). Pasture DMI and $\mathrm{N}$ excretion were estimated over a period of $6 \mathrm{~d}$. Pasture DMI was determined using the n-alkane technique of Dove and Mayes (2006). Cows were dosed with a paper bolus impregnated with $500 \mathrm{mg}$ of the n-alkane n-dotriacontane (C32) for a period of $12 \mathrm{~d}$ following am and pm milking. From d 6 to 12, samples of the concentrates, pasture,
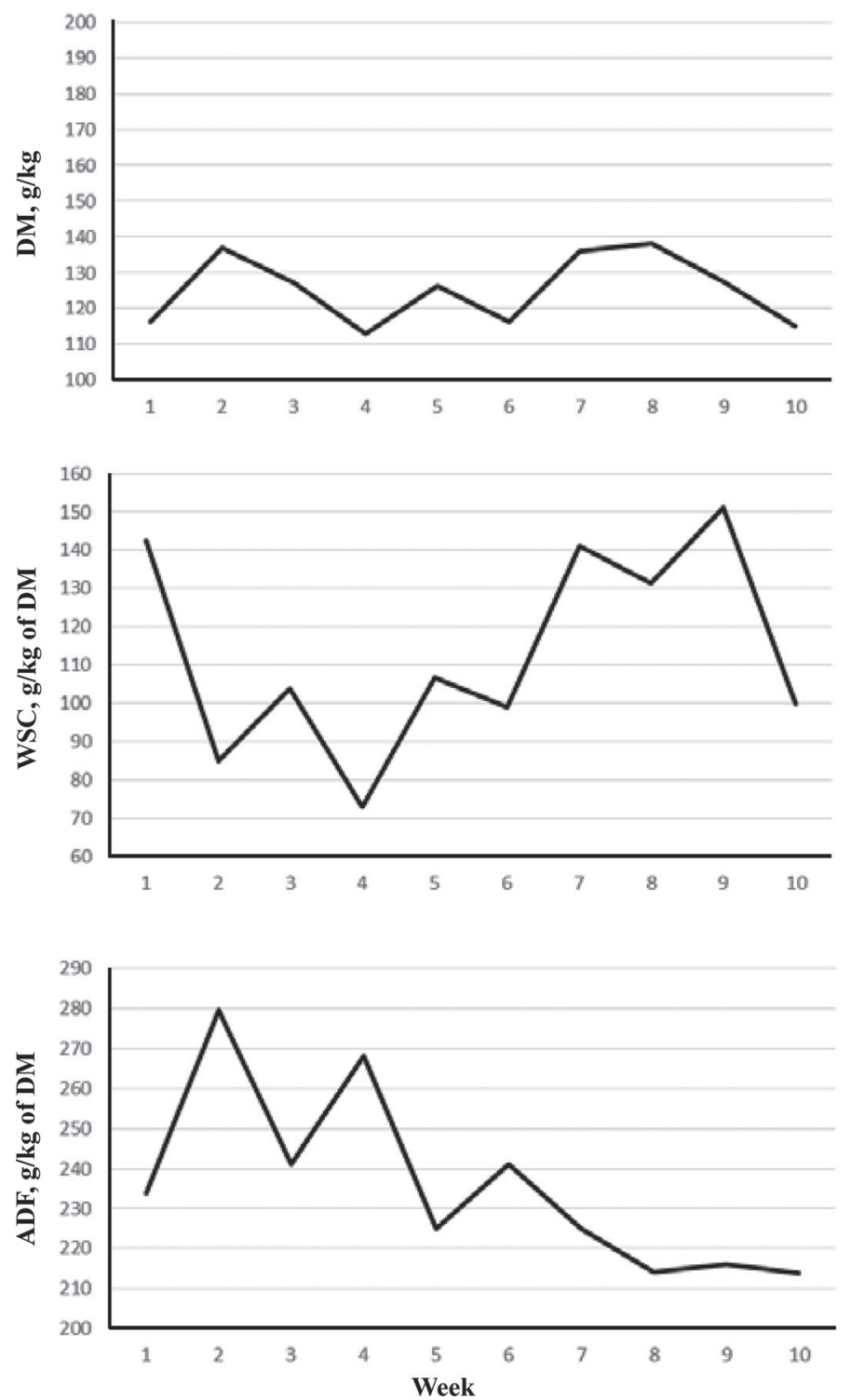

milk, and feces were collected. Pasture samples were collected morning and evening using a quadrat and handheld shears. These samples were immediately dried at $55^{\circ} \mathrm{C}$ for $48 \mathrm{~h}$. Fecal samples were collected, whenever possible, when cows naturally defecated, and, if not, samples were collected per rectum and placed in a forced-air oven at $55^{\circ} \mathrm{C}$ for $72 \mathrm{~h}$ or until dry. Samples of milk were collected during am and pm milking and pooled according to milk yield.

\section{Sample Analysis}

Feed and Fecal Sample Analysis. Pasture, concentrate, and fecal samples were dried in a forced-air
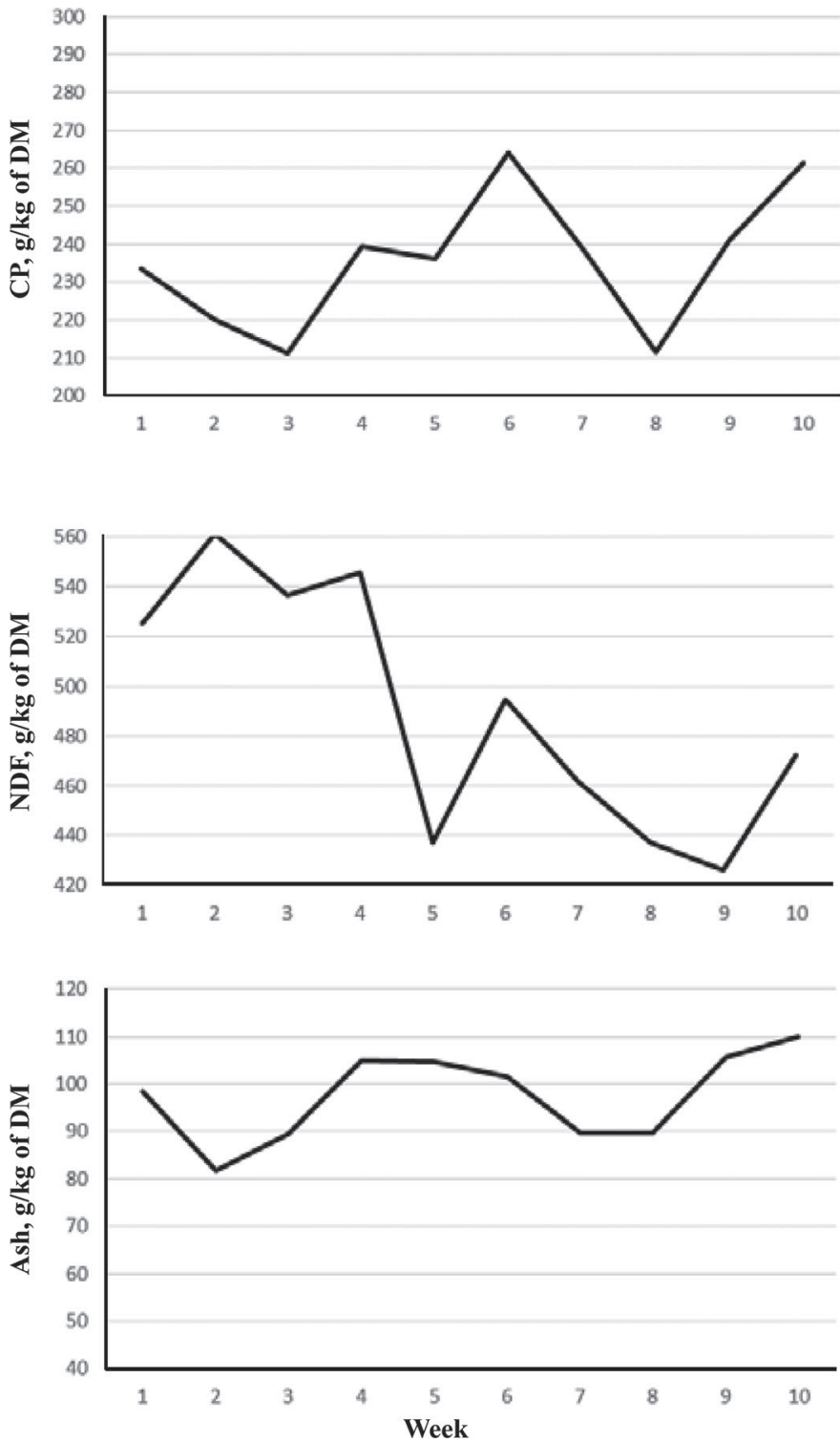

Figure 1. Changes in pasture quality offered to dairy cows in the autumn over the 10-wk experimental period (August 24 to October 27 , 2016). WSC = water-soluble carbohydrates. 


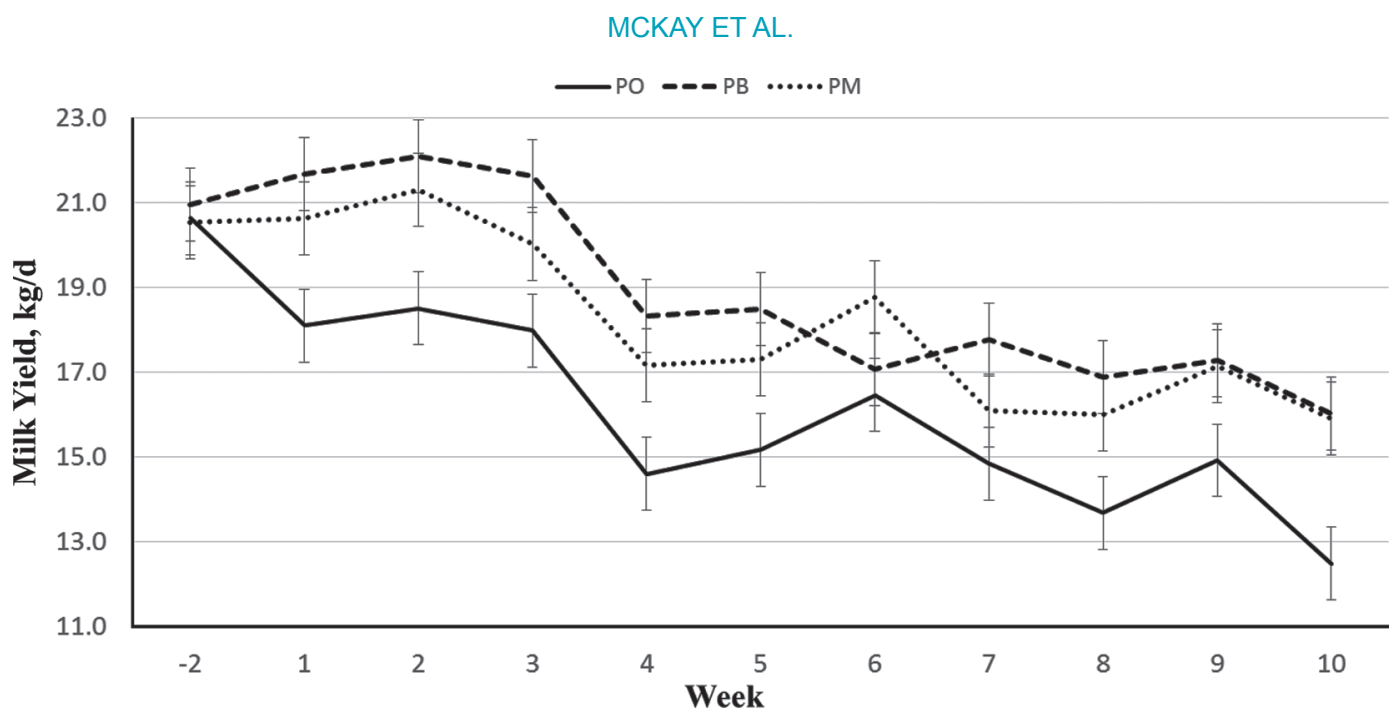

Figure 2. Changes in milk yield from the acclimatization period $(-2)$ over the 10-wk experimental period (August 24 to October 27, 2016). $\mathrm{PO}=$ pasture-only diet; $\mathrm{PB}=$ pasture plus barley-based concentrate supplement; $\mathrm{PM}=$ pasture plus maize-based concentrate supplement. Error bars: $\mathrm{SEM}=0.86$

oven at $55^{\circ} \mathrm{C}$ and were ground in a hammer mill fitted with a 1-mm screen (Lab Mill, Christy Turner, Ltd., Ipswich, UK). The DM content of samples was determined after drying overnight at $105^{\circ} \mathrm{C}(16 \mathrm{~h}$ minimum $)$ (AOAC International, 2005, method 930.15). The ash content was determined following combustion in a muffle furnace (Nabertherm GmbH, Lilienthal, Germany) at $550^{\circ} \mathrm{C}$ for $5.5 \mathrm{~h}$ (AOAC International, 2005, method 942.05). The $\mathrm{N}$ content of samples was determined by combustion on Leco and $\mathrm{CP}$ content calculated $(\mathrm{N} \times$ 6.25; FP 528 Analyzer, Leco Corp., St. Joseph, MI; AOAC International, 2005, method 990.03). The gross energy was determined by bomb calorimetry (Parr 1281 bomb calorimeter, Parr Instrument Company, Moline, IL). The ether extract content of feed samples was determined using Soxtec instruments (Tecator, Höganäs, Sweden) and light petroleum ether. Neutral detergent fiber and ADF were determined using the method Van Soest et al. (1991) adapted for use in the Ankom 220 Fiber Analyzer (Ankom Technology, Macedon, NY). This method included a thermostable $\alpha$-amylase and sodium sulfide, but residual ash was not determined. The starch and crude fiber (filter bag technique) contents were analyzed by FBA Laboratories (Cappoquin, Ireland). The concentration of WSC was determined as described by Dubois and colleagues (1956).

Cow Measurements Analysis. Concentrations of milk fat, protein, lactose, casein, urea, SCC, freezing point depression, and milk fatty acids were determined in a commercial milk laboratory (National Milk Laboratories Ltd., Wolverhampton, UK) using mid-infrared spectrometry (MilkoScan FT6000, Foss Analytical A/S, Hillerød, Denmark; Soyeurt et al., 2006). Values for
ECM, FCM to $40 \mathrm{~g} / \mathrm{kg}$, and fat- and protein-corrected milk (FPCM) were calculated as follows: ECM = $[(0.03273 \times$ milk yield $\mathrm{kg})+(7.65 \times$ milk protein $\mathrm{kg})$ $+(12.97 \times$ milk fat kg)] (Tyrrell and Reid, 1965); 40 $\mathrm{g} / \mathrm{kg}$ of $\mathrm{FCM}=[(0.4 \times$ milk yield $\mathrm{kg})+(15 \times$ fat yield $\mathrm{kg})]$ (Gaines and Davidson, 1923); FPCM $=[(0.337+$ $0.116 \times$ milk fat $\%+0.06 \times$ milk protein $\%) \times$ milk yield kg] (Sjaunja et al., 1990).

Blood samples were analyzed for glucose in the UCD veterinary clinical pathology laboratory (School of Veterinary Medicine, Dublin, Ireland) using Randox Kits according to manufacturer's instructions, with an RX IMOLA analyzer (Randox Laboratories, Crumlin, UK).

Rumen fluid was allowed to thaw in the refrigerator for $16 \mathrm{~h}$ at $4^{\circ} \mathrm{C}$ and was centrifuged at $2,100 \times g$ for 10 min at $4^{\circ} \mathrm{C}$. One milliliter of supernatant was diluted 1 in 5 with distilled $\mathrm{H}_{2} \mathrm{O}$ and then centrifuged at 1,600 $\times g$ for $15 \mathrm{~min}$ at $4^{\circ} \mathrm{C}$. Next, $200 \mu \mathrm{L}$ of supernatant was combined with 3 reagents and used to determine $\mathrm{NH}_{3}$ concentrations using a spectrophotometer. Rumen fluid was prepared for VFA analysis by mixing $250 \mu \mathrm{L}$ of rumen fluid with $3.75 \mathrm{~mL}$ of distilled $\mathrm{H}_{2} \mathrm{O}$; to this was added $1 \mathrm{~mL}$ of internal standard solution $(0.5 \mathrm{~g}$ of 3 -methylvaleric acid in $1,000 \mathrm{~mL}$ of $0.15 \mathrm{M}$ oxalic acid). The resulting solution was centrifuged at $1,600 \times g$ and filtered through a syringe-tip filter (PTFE, 13-mm diameter, $0.45 \mu \mathrm{m}$ ) into $2-\mathrm{mL} \mathrm{GC}$ vials. Concentrations of VFA were determined using GC (Varian 3800 GCL, Varian Inc., Palo Alto, CA) fitted with a 15-m capillary column with an internal diameter of $0.53 \mathrm{~mm}$, coated with $1.20 \mu \mathrm{m}$ thickness of acid-modified polyethylene glycol (EC-1000, Grace Davison Discovery Sciences, Lancashire, UK). 
Nitrogen Partitioning Study. Pasture DMI was determined by extracting n-alkanes from pasture, concentrate, and feces samples according to the method of Dove and Mayes (2006). Following extraction, samples were analyzed for concentrations of n-alkanes by GC using a Varian 3800 GLC (Varian Inc.) fitted with a 30-m capillary column with an internal diameter of $0.53 \mathrm{~mm}$, coated with $0.5 \mu \mathrm{m}$ of dimethyl polysiloxane (SGE Analytical Science Pty Ltd., Ringwood, Australia). These data were used to calculate $\mathrm{N}$ partitioning according to Whelan et al. (2012b) as follows: $\mathrm{N}$ intake $(\mathrm{g})=[(\mathrm{kg}$ of pasture DMI $\times \mathrm{g}$ of $\mathrm{N} / \mathrm{kg}$ of DM pasture $)$ $+(\mathrm{kg}$ of concentrate DMI $\times \mathrm{g}$ of $\mathrm{N} / \mathrm{kg}$ of DM concentrate)]; fecal $\mathrm{N}(\mathrm{g})=\mathrm{kg}$ of fecal $\mathrm{DM}$ excretion $\times \mathrm{g}$ of $\mathrm{N} / \mathrm{kg}$ of DM feces; milk $\mathrm{N}(\mathrm{g})=\mathrm{kg}$ of milk yield $\times \mathrm{g}$ of $\mathrm{N} / \mathrm{kg}$ of milk; and urine $\mathrm{N}(\mathrm{g})=\mathrm{N}$ intake $(\mathrm{g})-$ fecal $\mathrm{N}$ (g) - milk N (g).

\section{Statistical Analysis}

Data were checked for adherence to the normal distribution and homogeneity of variance using histograms and formal statistical tests as part of the Univariate procedure of SAS (version 9.3, 2012; SAS Institute Inc., Cary, NC). The natural logarithm transformation of milk SCC was used to normalize the distribution. The transformed data were used to calculate $P$-values. However, the corresponding least squares means and standard errors of the nontransformed data are presented in results for clarity (Al Ibrahim et al., 2010). Analysis of data was conducted using PROC MIXED of SAS (SAS Institute Inc.). The model included tests for the fixed effects of treatment, week, and their interactions. Cow live weight was included in the model as a covariate. Statistically significant differences between least squares means were tested using the PDIFF command, incorporating the Tukey test for pairwise comparison of treatment means. The model was adjusted for multiple comparisons using Bonferroni. Repeated measures (week) and random effects (cow) were also included in the model. Statistical significance was assumed at a value of $P<0.05$ and a tendency toward significance assumed at a value of $P>0.05$ but $<0.10$.

\section{RESULTS}

\section{DMI, BCS, Milk Production, and Milk Composition}

The effects of supplementation type on DMI, BCS, milk production, and milk composition are shown in Table 3. Cows offered PO had higher pasture DMI than PM $(P=0.03)$ but not PB $(P=0.30)$. Total DMI of cows offered PO was significantly lower than PB $(P=$ $0.03)$ but not PM $(P=0.23)$. Treatment had no effect on kilograms of ECM per kilogram of total DMI. Cow BCS was lower for PO compared with PM $(P=0.01)$ and tended to be lower than that of PB $(P=0.06)$. However, this small difference, although statistically significant, was not biologically significant.

Cows offered PO had a lower milk yield than those offered PB $(P<0.001)$ or PM $(P<0.001)$. Milk yield was higher for cows offered $\mathrm{PB}$ compared with cows offered PM $(P=0.003)$, and cows offered PB had significantly higher milk fat yield than those offered PO $(P<0.001)$ or PM $(P=0.001)$. Milk protein yield and milk lactose yield were higher for $\mathrm{PB}(P<0.001)$ and PM $(P=0.001)$ than for PO. Cows offered PB had increased milk protein yield compared with PM $(P$ $<0.001)$. Cows offered PB had increased lactose yield and casein yield compared with PM $(P=0.0015)$. Milk casein yield was higher for cows offered PB $(P<0.001)$ or PM $(P<0.001)$ than for those offered PO. Cows offered PO had higher milk fat concentration compared with PB $(P=0.001)$ or PM $(P<0.001)$. Milk lactose concentration was higher for cows supplemented with PB $(P=0.01)$ or PM $(P=0.02)$ compared with PO. Cows offered PO had higher milk urea nitrogen than those offered PB $(P=0.009)$ or PM $(P<0.001)$. Somatic cell count, protein concentration, and casein concentration were not affected by supplement type. Yields of ECM, FCM, and FPCM were lower for PO than for PB $(P<0.001)$ or PM $(P<0.02)$ and higher for cows offered $\mathrm{PB}$ compared with those offered PM $(P<0.001)$.

Table 4 shows the effect of supplementation type on milk $\mathrm{pH}$, freezing point depression, and milk fatty acids. Cows offered PO had a higher milk $\mathrm{pH}$ than those offered PM $(P<0.001)$ and tended also to be higher than those offered $\mathrm{PB}(P=0.08)$. However, cows supplemented with $\mathrm{PM}$ tended to have a lower milk $\mathrm{pH}$ than cows offered PB $(P=0.07)$. Milk total fatty acids were not affected by treatment.

\section{Rumen Fermentation and Blood Glucose}

Cows offered PM had a lower blood glucose concentration (Table 5) compared with those offered PO $(P=$ $0.01)$ or PB $(P<0.001)$. Cows offered PO had a higher ruminal $\mathrm{pH}$ than did those offered $\mathrm{PB}(P=0.004)$, and cows offered $\mathrm{PO}$ had lower total VFA concentration compared with $\mathrm{PB}(P=0.001)$. The $\mathrm{PB}$ supplement tended to increase the concentration of total VFA compared with PM $(P=0.08)$. The ratio of acetic acid to propionic acid was higher for PO than $\mathrm{PB}(P<0.001)$ or PM $(P<0.001)$. Cows offered PO had lower acetic acid concentration compared with $\mathrm{PB}(P=0.005)$. The cows offered PO had lower propionic acid than did those offered PB $(P<0.0001)$ or PM $(P<0.001)$. The 
Table 3. Effects of supplementation type on DMI, feed efficiency, BCS, milk production, and milk composition

\begin{tabular}{|c|c|c|c|c|c|}
\hline \multirow[b]{2}{*}{ Item } & \multicolumn{3}{|c|}{ Treatment $^{1}$} & \multirow[b]{2}{*}{ SEM } & \multirow[b]{2}{*}{$P$-value } \\
\hline & $\mathrm{PO}$ & $\mathrm{PB}$ & PM & & \\
\hline \multicolumn{6}{|l|}{ DMI } \\
\hline Pasture, $\mathrm{kg} / \mathrm{d}$ & $17.7^{\mathrm{a}}$ & $16.9^{\mathrm{ab}}$ & $15.9^{\mathrm{b}}$ & 0.56 & 0.09 \\
\hline Total, $\mathrm{kg} / \mathrm{d}$ & $17.7^{\mathrm{a}}$ & $19.5^{\mathrm{b}}$ & $18.5^{\mathrm{ab}}$ & 0.56 & 0.09 \\
\hline $\mathrm{kg}$ of $\mathrm{ECM} / \mathrm{kg}$ of DMI & 1.07 & 1.16 & 1.08 & 0.04 & 0.38 \\
\hline BCS & $2.61^{\mathrm{a}}$ & $2.68^{\mathrm{ab}}$ & $2.71^{\mathrm{b}}$ & 0.063 & 0.02 \\
\hline \multicolumn{6}{|l|}{ Milk production, $\mathrm{kg} / \mathrm{d}$} \\
\hline Milk yield & $15.1^{\mathrm{a}}$ & $18.2^{\mathrm{b}}$ & $16.8^{\mathrm{c}}$ & 0.86 & $<0.001$ \\
\hline Fat & $0.83^{\mathrm{a}}$ & $0.93^{\mathrm{b}}$ & $0.85^{\mathrm{a}}$ & 0.046 & $<0.001$ \\
\hline Protein & $0.60^{\mathrm{a}}$ & $0.73^{\mathrm{b}}$ & $0.65^{\mathrm{c}}$ & 0.011 & $<0.001$ \\
\hline Milk solids & $1.46^{\mathrm{a}}$ & $1.68^{\mathrm{b}}$ & $1.53^{\mathrm{c}}$ & 0.073 & $<0.001$ \\
\hline Lactose & $0.67^{\mathrm{a}}$ & $0.81^{\mathrm{b}}$ & $0.75^{\mathrm{c}}$ & 0.014 & $<0.001$ \\
\hline Casein & $0.50^{\mathrm{a}}$ & $0.60^{\mathrm{b}}$ & $0.54^{\mathrm{c}}$ & 0.024 & $<0.001$ \\
\hline \multicolumn{6}{|l|}{ Milk quality } \\
\hline Fat, $\%$ & $4.83^{\mathrm{a}}$ & $4.56^{\mathrm{b}}$ & $4.55^{\mathrm{b}}$ & 0.315 & $<0.001$ \\
\hline Protein, \% & 3.75 & 3.71 & 3.69 & 0.032 & 0.40 \\
\hline Casein, $\%$ & 3.55 & 3.50 & 3.50 & 0.112 & 0.42 \\
\hline Lactose, \% & $4.25^{\mathrm{a}}$ & $4.31^{\mathrm{b}}$ & $4.30^{\mathrm{b}}$ & 0.036 & 0.02 \\
\hline Urea, $\mathrm{mg} / \mathrm{dL}$ & $41^{\mathrm{a}}$ & $39^{\mathrm{b}}$ & $38^{\mathrm{b}}$ & 0.06 & $<0.001$ \\
\hline $\mathrm{SCC},{ }^{2}$ cells $/ \mathrm{mL}$ & 103 & 100 & 94 & 14.53 & 0.68 \\
\hline ECM. kg & $20.69^{\mathrm{a}}$ & $23.77^{\mathrm{b}}$ & $21.89^{\mathrm{c}}$ & 0.870 & $<0.001$ \\
\hline $4 \% \mathrm{FCM}, \mathrm{kg}$ & $18.70^{\mathrm{a}}$ & $21.33^{\mathrm{b}}$ & $19.68^{\mathrm{c}}$ & 0.828 & $<0.001$ \\
\hline $\mathrm{FPCM}^{3}{ }^{3} \mathrm{~kg}$ & $15.18^{\mathrm{a}}$ & $17.37^{\mathrm{b}}$ & $16.01^{\mathrm{c}}$ & 0.632 & $<0.001$ \\
\hline
\end{tabular}

${ }^{\mathrm{a} c}$ Within a row, means with different superscripts differ $(P<0.05)$.

${ }^{1} \mathrm{PO}=$ pasture-only diet; $\mathrm{PB}=$ pasture plus barley-based concentrate supplement; $\mathrm{PM}=$ pasture plus maizebased concentrate supplement.

${ }^{2}$ For SCC the natural logarithm transformed data were used to calculate $P$-values. The corresponding least squares means and standard errors of the nontransformed data are presented in results for clarity.

${ }^{3}$ Fat- and protein-corrected milk.

PB treatment group tended to have a higher propionic acid concentration compared with the PM group $(P=$ 0.08 ), and the cows offered PO had lower butyric acid than did those offered PB $(P<0.001)$ or PM $(P=$ 0.01). Cows offered PB or PM had higher proportions of acetic (PB $P=0.002 ; \mathrm{PM} P=0.02)$, propionic (PB $P<0.0001$; PM $P=0.0006)$, butyric $(\mathrm{PB} P=0.01$; PM $P=0.02)$, and isobutyric acid (PB $P=0.01 ; \mathrm{PM}$ $P=0.03)$ compared with those offered PO. Rumen ammonia, isobutyric acid, valeric acid, and isovaleric acid concentrations were not affected by treatment.

\section{Nitrogen Partitioning Study}

The effects of supplementation type on nitrogen partitioning are shown in Table 6. Dietary N intake did not differ significantly between treatments. However, cows offered PB had a greater output of $\mathrm{N}$ in milk compared

Table 4. Effects of supplementation type on milk $\mathrm{pH}$, freezing point depression, and milk fatty acids (FA)

\begin{tabular}{lccccc}
\hline & \multicolumn{3}{c}{ Treatment $^{1}$} \\
\cline { 2 - 4 } Item & PO & PB & PM & SEM & $P$-value \\
\hline Milk pH & $6.67^{\mathrm{a}}$ & $6.66^{\text {ab }}$ & $6.65^{\mathrm{b}}$ & 0.004 & 0.002 \\
Freezing point depression, ${ }^{\circ} \mathrm{C}$ & -0.537 & -0.538 & -0.536 & 0.9038 & 0.56 \\
Milk FA, g/100 g of milk fat & & & & & \\
MUFA & 28.87 & 29.33 & 29.52 & 0.730 & 0.11 \\
PUFA & 5.35 & 5.38 & 5.43 & 0.197 & 0.73 \\
SFA & 60.21 & 60.23 & 60.27 & 0.260 & 0.99 \\
UFA & 32.02 & 32.24 & 32.68 & 0.787 & 0.14 \\
Palmitic acid & 25.12 & 25.35 & 24.96 & 0.499 & 0.32 \\
Stearic acid & 8.84 & 8.89 & 8.84 & 0.284 & 0.92 \\
Oleic acid & 24.42 & 24.79 & 25.00 & 0.761 & 0.19 \\
\hline al & & & &
\end{tabular}

${ }_{\mathrm{a}, \mathrm{b}}$ Within a row, means with different superscripts differ $(P<0.05)$.

${ }^{1} \mathrm{PO}=$ pasture-only diet; $\mathrm{PB}=$ pasture plus barley-based concentrate supplement; $\mathrm{PM}=$ pasture plus maizebased concentrate supplement. 
Table 5. The effect of supplementation type on blood glucose concentration and rumen fermentation parameters

\begin{tabular}{lccccc}
\hline & \multicolumn{3}{c}{ Treatment $^{1}$} \\
Item & PO & PB & PM & SEM & P-value \\
\cline { 2 - 4 } & & & & \\
Blood glucose, mmol/L & $3.32^{\mathrm{a}}$ & $3.36^{\mathrm{a}}$ & $3.24^{\mathrm{b}}$ & 0.063 & 0.005 \\
Rumen pH & $6.32^{\mathrm{a}}$ & $6.23^{\mathrm{b}}$ & $6.27^{\mathrm{a}}$ & 0.079 & 0.02 \\
$\mathrm{NH}_{3}{ }^{2}$ mmol/L & 5.45 & 5.25 & 5.42 & 0.102 & 0.33 \\
VFA, mmol/L & & & & & \\
Total VFA & $89^{\mathrm{a}}$ & $94^{\mathrm{b}}$ & $92^{\mathrm{ab}}$ & 2.236 & 0.006 \\
Acetic:propionate & $5.79^{\mathrm{a}}$ & $5.34^{\mathrm{b}}$ & $5.45^{\mathrm{b}}$ & 0.224 & $<0.001$ \\
Acetic & $61.37^{\mathrm{a}}$ & $64.16^{\mathrm{b}}$ & $62.64^{\mathrm{ab}}$ & 0.709 & 0.02 \\
Propionic & $11.69^{\mathrm{a}}$ & $12.88^{\mathrm{b}}$ & $12.44^{\mathrm{b}}$ & 0.591 & $<0.001$ \\
Butyric & $11.52^{\mathrm{a}}$ & $12.56^{\mathrm{b}}$ & $12.19^{\mathrm{b}}$ & 0.187 & $<0.001$ \\
Isobutyric & 1.66 & 1.69 & 1.65 & 0.089 & 0.71 \\
Valeric & 1.86 & 1.91 & 1.94 & 0.182 & 0.53 \\
Isovaleric & 1.68 & 1.72 & 1.72 & 0.088 & 0.46 \\
VFA proportions, mmol/L & & & & & \\
Acetic & $0.6983^{\mathrm{a}}$ & $0.6881^{\mathrm{b}}$ & $0.6902^{\mathrm{b}}$ & 0.00522 & 0.005 \\
Propionic & $0.1249^{\mathrm{a}}$ & $0.1315^{\mathrm{b}}$ & $0.1298^{\mathrm{b}}$ & 0.00350 & $<0.001$ \\
Butyric & $0.1276^{\mathrm{a}}$ & $0.1322^{\mathrm{b}}$ & $0.1321^{\mathrm{b}}$ & 0.00344 & 0.02 \\
Isobutyric & $0.0183^{\mathrm{a}}$ & $0.0176^{\mathrm{b}}$ & $0.0176^{\mathrm{b}}$ & 0.00021 & 0.03 \\
Valeric & 0.0190 & 0.0191 & 0.0194 & 0.00177 & 0.93 \\
Isovaleric & 0.0184 & 0.0180 & 0.0183 & 0.00070 & 0.32 \\
\hline
\end{tabular}

${ }^{\mathrm{a}, \mathrm{b}}$ Within a row, means with different superscripts differ $(P<0.05)$.

${ }^{1} \mathrm{PO}=$ pasture-only diet $\mathrm{PB}=$ pasture plus barley-based concentrate supplement; $\mathrm{PM}=$ pasture plus maizebased concentrate supplement.

${ }^{2}$ Rumen ammonia.

with those offered PO $(P=0.008)$. Cows offered PM had lower fecal $\mathrm{N}$ output than did those offered $\mathrm{PO}(P$ $=0.03)$ or $\mathrm{PB}(P=0.04)$. The proportion of ingested $\mathrm{N}$ excreted in the feces was higher for cows offered PO than for those offered PM $(P=0.01)$ and tended also to be higher for cows offered PO compared with those offered PB $(P=0.08)$. However, concentrate supplementation had no effect on total $\mathrm{N}$ excretion or NUE.

\section{DISCUSSION}

In Ireland, milk is primarily produced from a spring-calving grass-based system, with concentrate supplementation mainly when there is a reduction in pasture availability and quality (Coleman et al., 2010; Creighton et al., 2011; McCarthy et al., 2013). Benefits of concentrate supplementation include increased milk

Table 6. Effects of supplementation type on nitrogen $(\mathrm{N})$ partitioning

\begin{tabular}{|c|c|c|c|c|c|}
\hline \multirow[b]{2}{*}{ Item } & \multicolumn{3}{|c|}{ Treatment $^{1}$} & \multirow[b]{2}{*}{ SEM } & \multirow[b]{2}{*}{$P$-value } \\
\hline & $\mathrm{PO}$ & $\mathrm{PB}$ & $\mathrm{PM}$ & & \\
\hline \multicolumn{6}{|l|}{ Intake, $\mathrm{kg} / \mathrm{d}$} \\
\hline Feed N & 0.771 & 0.815 & 0.773 & 0.0243 & 0.38 \\
\hline \multicolumn{6}{|l|}{$\mathrm{N}$ excreted, $\mathrm{kg} / \mathrm{d}$} \\
\hline Milk & $0.099^{\mathrm{a}}$ & $0.115^{\mathrm{b}}$ & $0.106^{\mathrm{ab}}$ & 0.0038 & 0.03 \\
\hline Feces & $0.179^{\mathrm{a}}$ & $0.179^{\mathrm{a}}$ & $0.164^{\mathrm{b}}$ & 0.0102 & 0.05 \\
\hline Urine & 0.499 & 0.527 & 0.510 & 0.0200 & 0.62 \\
\hline \multicolumn{6}{|l|}{$\mathrm{N}$ partitioning ${ }^{2}$} \\
\hline Milk & 0.129 & 0.141 & 0.137 & 0.005 & 0.158 \\
\hline Feces & $0.231^{\mathrm{a}}$ & $0.217^{\mathrm{ab}}$ & $0.211^{\mathrm{b}}$ & 0.010 & 0.03 \\
\hline Urine & 0.646 & 0.647 & 0.657 & 0.008 & 0.56 \\
\hline $\mathrm{N}$ excreted, ${ }^{3} \%$ & 87.15 & 85.87 & 86.26 & 0.535 & 0.162 \\
\hline $\mathrm{NUE}^{4} \%$ & 12.87 & 14.16 & 13.74 & 0.535 & 0.162 \\
\hline
\end{tabular}

a,b Within a row, means with different superscripts differ $(P<0.05)$.

${ }^{1} \mathrm{PO}=$ pasture-only diet; $\mathrm{PB}=$ pasture plus barley-based concentrate supplement; $\mathrm{PM}=$ pasture plus maizebased concentrate supplement.

${ }^{2} \mathrm{~N}$ proportions $=\mathrm{N}$ out $[$ feces, urine, milk $(\mathrm{kg} / \mathrm{d})] / \mathrm{N}$ intake $(\mathrm{kg} / \mathrm{d})$.

${ }^{3} \mathrm{~N}$ excreted $=\mathrm{N}$ out $\{[$ feces + urine output $(\mathrm{kg} / \mathrm{d})] / \mathrm{N}$ intake $(\mathrm{kg} / \mathrm{d})\} \times 100$

${ }^{4}$ Nitrogen utilization efficiency $=\mathrm{N}$ out $\{[$ milk output $(\mathrm{kg} / \mathrm{d})] / \mathrm{N}$ intake $(\mathrm{kg} / \mathrm{d})\} \times 100$. 
production and reduced $\mathrm{N}$ excretion (Whelan et al., $2012 \mathrm{a}, \mathrm{b})$. However, there is a paucity of information on effects of different types of concentrates on cow performance. Therefore, the objective of this research was to investigate the effects of different concentrate supplementation types, based on barley or maize, on milk production, milk composition, DMI, rumen fermentation, and $\mathrm{N}$ excretion in late-lactation, spring-calving grazing dairy cows.

\section{DMI, Substitution Rate, Milk Production, and Milk Composition}

The current study observed that concentrate supplementation type affects pasture DMI, as PM reduced pasture intake compared with PO. Mackle et al. (1999) offered maize grain to dairy cows in late lactation and observed a reduction in pasture DMI in comparison to cows offered pasture only. The reduction in pasture DMI in PM cows is supported by the substitution rate ( $\mathrm{kg}$ of reduction in pasture DMI per $\mathrm{kg}$ of DMI of concentrate; Kellaway and Harrington, 2004), observed as PM $(0.68 \mathrm{~kg})$ had a higher substitution rate than PB $(0.31 \mathrm{~kg})$. These substitution rates are in line with Stakelum (1986), who reported, with an autumn pasture allowance of 16 and $24 \mathrm{~kg}$ of DM/cow per day and a concentrate allocation of $3.3 \mathrm{~kg}$ of DM/cow per day, a substitution rate of 0.28 and 0.59 , respectively, for cows in late lactation. Furthermore, as PB had a lower substitution rate, total DMI increased significantly compared with PO. In this experiment, a milk response of $1.21 \mathrm{~kg}$ and $0.71 \mathrm{~kg}$ of milk/ $\mathrm{kg}$ of concentrate (calculated as the difference in milk produced between unsupplemented and supplemented treatment divided by concentrate DMI) was observed for PB and PM respectively, which agrees with the findings of Gleeson (1981), Mackle et al. (1999), and Lovett et al. (2005), who observed a response to concentrates in the autumn ranging from 0.5 to $1.18 \mathrm{~kg}$ of milk/ $\mathrm{kg}$ of concentrate. Compared with offering cows PO, supplementation with PB or PM increased milk yield and milk solids yield in the current study. Reid et al. (2015) also observed an increased milk yield $(+3 \mathrm{~kg} / \mathrm{d})$ and milk solids yield $(+0.4 \mathrm{~kg} / \mathrm{d})$ for cows in late lactation offered $3 \mathrm{~kg}$ of a $30 \%$ barley supplement in comparison to cows offered PO. Mackle et al. (1999) offered dairy cows in late lactation (203 DIM) ryegrass and white clover pasture supplemented with 2 to $3 \mathrm{~kg}$ of maize corn and observed an increase in milk yield of $1.5 \mathrm{~kg} / \mathrm{d}$ compared with cows offered pasture only.

In the current study, we hypothesized that altering the starch type in the concentrate, from a rapidly degradable to a more slowly degradable type, would have a positive effect on milk production and milk composi- tion, as maize may improve the energy supply to the mammary gland (Lemosquet et al., 2009). Whelan et al. (2012a) offered dairy cows in early lactation (30 DIM) a pasture-based diet with a higher level $(5.17 \mathrm{~kg}$ of $\mathrm{DM} / \mathrm{d}$ ) of a barley- or maize-based supplement and observed improvements in milk yield, milk fat concentration, milk protein concentration, and milk lactose concentration in cows offered the maize supplementation. The authors surmised that replacing barley with maize increased milk yield due to the additional postruminal degradable starch from maize. In contrast, the present study found that cows offered PB had a higher milk yield than those offered PM. The differences observed may be due primarily to differences in pasture quality between the 2 studies. Throughout the grazing season, pasture availability and quality change, affecting the nutritional composition and nutrient supply to the cow. Auldist et al. (1998). Beever et al. (1986) reported that autumn pasture has a lower energy value than does spring, slower rumen breakdown, and higher cell wall lignification, supporting the grass quality results reported in this research. The pasture in Whelan et al. (2012a) was higher in WSC $(188 \mathrm{~g} / \mathrm{kg})$ and had lower NDF (460 g/kg) compared with the current study (113 g/kg WSC and $490 \mathrm{~g} / \mathrm{kg}$ NDF, respectively). The increased milk production and blood glucose concentration of cows consuming the barley-based concentrate compared with maize in this study may be due to barley having a greater ruminal degradation and lower rumen bypass starch than maize (Theurer, 1986), thus complementing the autumn pasture offered that was high in NDF and limiting in energy.

Although Delagarde et al. (1999) stated that modifying the carbohydrate type showed little benefit to grazing dairy cows when offered feeding levels of $3 \mathrm{~kg}$ of $\mathrm{DM} / \mathrm{d}$, the differences in performance observed between supplement types in the current study highlight the potential of altering the type of concentrate supplementation to dairy cows in late lactation, with benefits from PB observed.

\section{Rumen Fermentation and Blood Glucose}

Supplemented cows had increased milk yield and milk lactose concentration, which is supported by the higher concentration and higher proportion of rumen propionic acid and reduced ratio of acetic to propionic acid. Propionic acid is a precursor for milk lactose, which, being the main osmotic component of milk, regulates milk yield (Shamay et al., 2003; Aschenbach et al., 2010).

It is well documented that offering $2 \mathrm{~kg}$ of $\mathrm{DM} / \mathrm{d}$ plus concentrate supplementation to pasture reduces milk fat concentration (O'Brien et al., 1996; Bargo 
et al., 2003) because starch reduces rumen $\mathrm{pH}$, alters rumen biohydrogenation, and reduces milk fat content (Van Nevel and Demeyer, 1996; Kalscheur et al., 1997; Martin et al., 2006). In agreement with this, the supplemented cows showed lower milk fat concentration, compared with pasture-only cows. The higher NDF of the pasture resulted in a higher rumen ratio of acetate to propionate, compared with cows supplemented with PB or PM. Similarly, Mackle et al. (1999) observed that cows offered PO had a higher milk fat content compared with cows offered a maize supplement.

The type of supplementation altered rumen fermentation, as evidenced by increased total VFA production from $\mathrm{PB}$ compared with $\mathrm{PO}$. Although ruminal $\mathrm{pH}$ was reduced in cows offered $\mathrm{PB}$, values for all treatments were above 6.2 , the value considered optimal for the growth of cellulolytic bacteria in the rumen (Ørskov, 1999). As well as increased total VFA concentration from offering $\mathrm{PB}$ compared with $\mathrm{PO}, \mathrm{PB}$ cows had increased concentrations and proportions of acetic, propionic, and butyric acids. Bargo et al. (2002) also reported a reduction in ruminal $\mathrm{pH}$ and an increase in total VFA concentration when concentrate supplementation is offered. However, in contrast, Khalili and Sairanen (2000) reported no difference in ruminal $\mathrm{pH}$ or total VFA concentration when offering barley as a supplement to grazed pasture. However, this may have been due to the difference in nutritive value of pasture species in that study (timothy and meadow fescue) compared with the current study (perennial ryegrass), because timothy and meadow fescue have a lower digestibility than perennial ryegrass, which may alter rumen conditions and reduce passage rate and subsequent concentrations of VFA (Frame and Laidlaw, 2011). Rumen conditions of cows offered PM were similar to PO, and this may be due to maize having a higher rumen bypass starch than barley, with almost $40 \%$ of starch digestion occurring post-ruminally (Kay et al., 1972; Herrera-Saldana et al., 1990). The positive effect of barley on VFA production further indicates that PB may be more advantageous than PM in late lactation with cows consuming autumn pasture.

\section{Nitrogen Partitioning Study}

Large proportions (0.7 to 0.8) of ingested $\mathrm{N}$ are excreted from dairy cows (Ryan et al., 2011), which has detrimental effects on the environment (Tamminga, 1992; Whelan et al., 2012b). A greater problem in pasture-based systems, compared with confinement systems, is that a large proportion of $\mathrm{N}$ is lost to the environment through volatilization and leaching when cows are grazing outdoors (Hyde et al., 2003; Casey and Holden, 2005; Ryan et al., 2011).
In the current study, changes in the partitioning of $\mathrm{N}$ into feces were observed, although concentrate supplementation did not increase milk or reduce urinary $\mathrm{N}$ excretion, as might be expected with additional fermentable energy in the diet (Kebreab et al., 2000; Castillo, 2001). However, as pasture DMI was similar among treatments, dietary $\mathrm{N}$ intake was also similar, and at the low level $(2.65 \mathrm{~kg}$ of $\mathrm{DM} / \mathrm{d})$ of concentrate that was offered, rumen degradable energy may have been limiting, and subsequent utilization of the $\mathrm{N}$ may have been poor and not sufficient to alter $\mathrm{N}$ partitioning significantly to reduce $\mathrm{N}$ excretion. In comparison, Burke et al. (2008) and Reid et al. (2015) reported that NUE was improved by offering supplementation at pasture in mid- and late lactation. In that study, however, higher levels of concentrate supplementation (4 $\mathrm{kg}$ of $\mathrm{DM} / \mathrm{d}$ and $3 \mathrm{~kg}$ of $\mathrm{DM} / \mathrm{d}$, respectively) and lower pasture $(15 \mathrm{~kg}$ of $\mathrm{DM} / \mathrm{d}$ and $14 \mathrm{~kg}$ of $\mathrm{DM} / \mathrm{d}$, respectively) allocations were offered, which may have provided extra degradable energy to utilize the additional $\mathrm{N}$ and improve the efficiency of $\mathrm{N}$ into microbial mass and subsequently the supply of amino acids into the small intestine (Schor and Gagliostro, 2001). In agreement, Whelan et al. (2012b) offered dairy cows in early lactation pasture plus barley or maize supplementation at a higher level $(5.17 \mathrm{~kg} / \mathrm{d})$ and observed lower urinary $\mathrm{N}$ excretion with the maize supplement, due to an improvement in amino acid supply and milk protein yield.

It has been previously reported that as DIM increases, NUE decreases, as milk yield naturally declines and $\mathrm{N}$ excreted in the feces and urine increases (Castillo, 2001). In early lactation, cows offered pasture and concentrate retain approximately $25 \%$ of $\mathrm{N}$ intake (Mulligan et al., 2004; Whelan et al., 2012b), but as lactation progresses, this figure decreases to approximately $18 \%$ for cows in mid-lactation offered pasture (Burke et al., 2008) and to 11 to $12 \%$ in late lactation (Reid et al., 2015), a figure similar to that observed in this study. However, we found that supplementation with PB tended to improve NUE from 12 to $14 \%$, compared with PO, possibly due to the increased amount of milk N.

\section{CONCLUSIONS}

Concentrate supplementation based on barley or maize resulted in increased milk yield and milk solids yield compared with offering PO. Cows offered PB had a greater milk response to concentrates ( $\mathrm{kg}$ of milk/ $\mathrm{kg}$ of concentrate) and higher milk and milk solids yields than did cows offered PM. Additionally, cows offered $\mathrm{PB}$ showed higher $\mathrm{N}$ excretion in milk than those offered PO. The PB concentrate increased total 
DMI compared with PO, due to a lower substitution rate than PM. This study highlights the potential of altering the type of concentrate supplementation in late lactation to improve milk production and DMI when pasture availability and quality is limited. However, the economic benefit of the increase in milk yield and milk solids from offering concentrate supplementation must also be considered.

\section{ACKNOWLEDGMENTS}

Funding for this research was provided under the Innovative Dairy Production Systems and Technologies (Dairy Tech) Innovation Partnership Programme through the Enterprise Ireland Innovation Partnership Programme (Dublin, Ireland), which is co-funded by the European Regional Development Fund (ERDF) under Ireland's European Structural and Investment Funds Programmes 2014-2020. Additionally, the authors acknowledge the contribution of the farm and laboratory staff at UCD Lyons Research Farm.

\section{REFERENCES}

Al Ibrahim, R. M., A. K. Kelly, L. O'Grady, V. P. Gath, C. McCarney, and F. J. Mulligan. 2010. The effect of body condition score at calving and supplementation with Saccharomyces cerevisiae on milk production, metabolic status, and rumen fermentation of dairy cows in early lactation. J. Dairy Sci. 93:5318-5328.

AOAC International. 2005 Official Methods of Analysis. 18th ed. AOAC International, Gaithersburg, MD.

Aschenbach, J. R., N. B. Kristensen, S. S. Donkin, H. M. Hammon, and G. B. Penner. 2010. Gluconeogenesis in dairy cows: The secret of making sweet milk from sour dough. IUBMB Life 62:869-877.

Auldist, M. J., B. J. Walsh, and N. A. Thomson. 1998. Seasonal and lactational influences on bovine milk composition in New Zealand. J. Dairy Res. 65:401-411.

Bargo, F., L. Muller, E. Kolver, and J. Delahoy. 2003. Invited review: Production and digestion of supplemented dairy cows on pasture. J. Dairy Sci. 86:1-42

Bargo, F., L. D. Muller, J. E. Delahoy, and T. W. Cassidy. 2002. Milk response to concentrate supplementation of high producing dairy cows grazing at two pasture allowances. J. Dairy Sci. 85:1777-1792.

Beever, D. E., M. S. Dhanoa, H. R. Losada, R. T. Evans, S. B. Cammell, and J. France. 1986. The effect of forage species and stage of harvest on the processes of digestion occurring in the rumen of cattle. Br. J. Nutr. 56:439-454.

Burke, F., M. A. O'Donovan, J. J. Murphy, F. P. O'Mara, and F. J. Mulligan. 2008. Effect of pasture allowance and supplementation with maize silage and concentrates differing in crude protein concentration on milk production and nitrogen excretion by dairy cows. Livest. Sci. 114:325-335.

Casey, J. W., and N. M. Holden. 2005. Analysis of greenhouse gas emissions from the average Irish milk production system. Agric. Syst. 86:97-114

Castillo, A. 2001. Improving nitrogen utilisation in dairy cows. $\mathrm{PhD}$ Thesis. University of Reading, UK.

Coleman, J., K. M. Pierce, D. P. Berry, A. Brennan, and B. Horan. 2010. Increasing milk solids production across lactation through genetic selection and intensive pasture-based feed system. J. Dairy Sci. 93:4302-4317.

Creighton, P., E. Kennedy, L. Shalloo, T. M. Boland, and M. O'Donovan. 2011. A survey analysis of grassland dairy farming in
Ireland, investigating grassland management, technology adoption and sward renewal. Grass Forage Sci. 66:251-264.

CSO. 2015. Central Statistics Office, Milk Statistics December 2015. Accessed Oct. 2, 2018. https://www.cso.ie/ en/releasesandpublications/er/ms/milkstatisticsdecember2015.

CSO. 2017a. Central Statistics Office, Agriculture Selected Livestock numbers in December 2017. Accessed Oct. 2, 2018.https://www .cso.ie/multiquicktables/quickTables.aspx? id=aaa06.

CSO. 2017b. Central Statistics Office, Milk Statistics December 2017. Accessed Oct. 2, 2018. https://www.cso.ie/en/ releasesandpublications/er/ms/milkstatisticsdecember2017/.

Delagarde, R., J. L. Peyraud, and L. Deyaby. 1999. Influence of carbohydrate or protein supplementation on intake, behaviour and digestion in dairy cows strip-grazing low-nitrogen fertilized perennial ryegrass. Ann. Zootech. 48:81-96.

Dove, H., and R. W. Mayes. 2006. Protocol for the analysis of n-alkanes and other plant-wax compounds and for their use as markers for quantifying the nutrient supply of large mammalian herbivores. Nat. Protoc. 1:1680-1697.

Dubois, M. K. A. Gilles, J. K. Hamilton, P. T. Rebers, and F. Smith. 1956. Colorimetric method for determination of sugars and related substances. Anal. Chem. 28:350-356.

Edmonson, A. J., I. J. Lean, L. D. Weaver, T. Farver, and G. Webster 1989. A body condition scoring chart for Holstein dairy cows. J. Dairy Sci. 72:68-78.

Finneran, E., P. Crosson, P. O'Kiely, L. Shalloo, D. Forristal, and M. Wallace. 2010. Simulation modelling of the cost of producing and utilising feeds for ruminants on Irish farms. J. Farm Manag. 14:95-116.

Frame, J., and A. S. Laidlaw. 2011. Feeding Value of Grass. P173. Improved grassland management (No. Ed. 2). The Crowood Press Ltd., Wiltshire, UK.

Gaines, W. L., and F. A. Davidson. 1923. Relation between percentage fat content and yield of milk, correction of milk yield for fat content. Agric. Exp. Sta. Bull. 245:577-621.

Gleeson, P. A. 1981. Concentrate supplementation for spring calving cows. Grass Forage Sci. 36:138-141.

Herrera-Saldana, R. E., J. T. Huber, and M. H. Poore. 1990. Dry matter, crude protein, and starch degradability of five cereal grains. J. Dairy Sci. 73:2386-2393.

Hyde, B. P., O. T. Carton, P. O'Toole, and T. H. Misselbrook. 2003. A new inventory of ammonia emissions from Irish agriculture. At mos. Environ. 37:55-62.

Kalscheur, K. F., B. B. Teter, L. S. Piperova, and R. A. Erdman. 1997. Effect of dietary forage concentration and buffer addition on duodenal flow of trans-c18:1 fatty acids and milk fat production in dairy cows. J. Dairy Sci. 80:2104-2114.

Kay, M., N. A. MacLeod, and A. Pavlicević. 1972. The value of different cereals in diets for growing steers. Proc. Nutr. Soc. 31:57A

Kebreab, E., A. R. Castillo, D. E. Beever, D. J. Humphries, and J. France. 2000. Effects of management practices prior to and during ensiling and concentrate type on nitrogen utilization in dairy cows. J. Dairy Sci. 83:1274-1285.

Kellaway, R., and T. Harrington. 2004. Feeding Concentrates: Supplements for Dairy Cows. Landlinks Press, Melbourne, Australia.

Khalili, H., and A. Sairanen. 2000. Effect of concentrate type on rumen fermentation and milk production of cows at pasture. Anim. Feed Sci. Technol. 84:199-212.

Lacy-Hulbert, S. J., M. W. Woolford, G. D. Nicholas, C. G. Prosser, and K. Stelwagen. 1999. Effect of milking frequency and pasture intake on milk yield and composition of late lactation cows. J. Dairy Sci. 82:1232-1239.

Lemosquet, S., E. Delamaire, H. Lapierre, J. W. Blum, and J. L. Peyraud. 2009. Effects of glucose, propionic acid, and nonessential amino acids on glucose metabolism and milk yield in Holstein dairy cows. J. Dairy Sci. 92:3244-3257.

Lovett, D. K., L. J. Stack, S. Lovell, J. Callan, B. Flynn, M. Hawkins, and F. P. O'Mara. 2005. Manipulating enteric methane emissions and animal performance of late-lactation dairy cows through concentrate supplementation at pasture. J. Dairy Sci. 88:2836-2842. 
Lucey, J. A., and P. F. Fox. 1992. Rennet coagulation properties of late-lactation milk: Effect of $\mathrm{pH}$ adjustment, addition of $\mathrm{CaCl}_{2}$, variation in rennet level and blending with mid-lactation milk. Ir. J. Agric. Food Res. 31:173-184.

Mackle, T. R., A. M. Bryant, S. F. Petch, R. J. Hooper, and M. J. Auldist. 1999. Variation in the composition of milk protein from pasture-fed dairy cows in late lactation and the effect of grain and silage supplementation. N. Z. J. Agric. Res. 42:147-154.

Martin, C., L. Brossard, and M. Doreau. 2006. Mechanisms of appearance of ruminal acidosis and consequences on physiopathology and performances. Prod. Anim. 19:93-107.

McCarthy, B., K. M. Pierce, L. Delaby, A. Brennan, C. Fleming, and B. Horan. 2013. The effect of stocking rate and calving date on grass production, utilization and nutritive value of the sward during the grazing season. Grass Forage Sci. 68:364-377.

Mulligan, F. J., P. Dillon, J. J. Callan, M. Rath, and F. P. O'Mara. 2004. Supplementary concentrate type affects nitrogen excretion of grazing dairy cows. J. Dairy Sci. 87:3451-3460.

O'Brien, B., S. Crosse, and P. Dillon. 1996. Effects of offering a concentrate or silage supplement to grazing dairy cows in late lactation on animal performance and on milk processability. Ir. J. Agric. Food Res. 35:113-125.

Ørskov, E. R. 1986. Starch digestion and utilization in ruminants. J. Anim. Sci. 63:1624-1633.

Ørskov, E. R. 1999. Supplement strategies for ruminants and management of feeding to maximize utilization of roughages. Prev. Vet. Med. 38:179-185.

Reid, M., M. O’Donovan, J. P. Murphy, C. Fleming, E. Kennedy, and E. Lewis. 2015. The effect of high and low levels of supplementation on milk production, nitrogen utilization efficiency, and milk protein fractions in late-lactation dairy cows. J. Dairy Sci. 98:5529-5544.

Ryan, W., D. Hennessy, J. J. Murphy, T. M. Boland, and L. Shalloo. 2011. A model of nitrogen efficiency in contrasting grass-based dairy systems. J. Dairy Sci. 94:1032-1044.

Schor, A., and G. A. Gagliostro. 2001. Undegradable protein supplementation to early-lactation dairy cows in grazing conditions. J. Dairy Sci. 84:1597-1606.
Shamay, A., F. Shapiro, G. Leitner, and N. Silanikove. 2003. Infusions of casein hydrolyzates into the mammary gland disrupt tight junction integrity and induce involution in cows. J. Dairy Sci. $86: 1250-1258$.

Sjaunja, L. O., L. Baevre, L. Junkkarinen, J. Pedersen, and J. Setala. 1990. A Nordic proposal for an energy corrected milk (ECM) formula. In 27th session of the International Commission for Breeding and Productivity of Milk Animals, Paris, France. EAAP Publication No. 50. Pudoc, Wageningen, the Netherlands.

Soyeurt, H., P. Dardenne, F. Dehareng, G. Lognay, D. Veselko, M. Marlier, C. Bertozzi, P. Mayeres, and N. Gengler. 2006. Estimating fatty acid content in cow milk using mid-infrared spectrometry. J. Dairy Sci. 89:3690-3695.

Stakelum, G. 1986. Herbage intake of grazing dairy cows: 1. Effect of autumn supplementation with concentrates and herbage allowance on herbage intake. Isr. J. Agric. Res. 25:31-40.

Tamminga, S. 1992. Nutrition management of dairy cows as a contribution to pollution control. J. Dairy Sci. 75:345-357.

Theurer, C. B. 1986. Grain processing effects on starch utilization by ruminants. J. Anim. Sci. 63:1649-1662.

Tyrrell, H. F., and J. T. Reid. 1965. Prediction of the energy value of cow's milk. J. Dairy Sci. 48:1215-1223.

Van Nevel, C. J., and D. I. Demeyer. 1996. Influence of $\mathrm{pH}$ on lipolysis and biohydrogenation of soybean oil by rumen contents in vitro. Reprod. Nutr. Dev. 36:53-63.

Van Soest, P. J., J. B. Robertson, and B. A. Lewis. 1991. Methods for dietary fiber, neutral detergent fiber, and nonstarch polysaccharides in relation to animal nutrition. J. Dairy Sci. 74:3583-3597.

Whelan, S. J., K. M. Pierce, B. Flynn, and F. J. Mulligan. 2012a. Effect of supplemental concentrate type on milk production and metabolic status in early-lactation dairy cows grazing perennial ryegrass-based pasture. J. Dairy Sci. 95:4541-4549.

Whelan, S. J., K. M. Pierce, C. McCarney, B. Flynn, and F. J. Mulligan. 2012b. Effect of supplementary concentrate type on nitrogen partitioning in early lactation dairy cows offered perennial ryegrass-based pasture. J. Dairy Sci. 95:4468-4477. 